\title{
Oral administration of cobalt acetate alters milk fatty acid composition, consistent with an inhibition of stearoyl-coenzyme A desaturase in lactating ewes
}

\author{
P. Frutos, ${ }^{11}$ P. G. Toral, ${ }^{\star}$ E. Ramos-Morales, $\dagger^{\star}$ K. J. Shingfield,‡ A. Belenguer, ${ }^{\star}$ and G. Hervás* \\ *Instituto de Ganadería de Montaña (CSIC-ULE), Finca Marzanas s/n, 24346 Grulleros, León, Spain \\ †Estación Experimental del Zaidín (CSIC), Profesor Albareda 1, 18008 Granada, Spain \\ ¥Animal Production Research, MTT Agrifood Research Finland, FI-31600, Jokioinen, Finland
}

\begin{abstract}
Previous investigations have shown that cobalt (Co) modifies milk fat composition in cattle, consistent with an inhibition of stearoyl-coenzyme A desaturase (SCD) activity, but it remains unclear whether other ruminant species are also affected. The present study examined the effects of oral administration of Co acetate on intake, rumen function, and milk production and fatty acid (FA) composition in sheep. Twenty lactating Assaf ewes were allocated into 1 of 4 groups and used in a continuous randomized block design that involved a $15-\mathrm{d}$ adaptation, a 6-d treatment, and a 10-d posttreatment period. During the treatment period, animals received an oral drench supplying 0 (control), 3 (Co3), 6 (Co6), and 9 (Co9) $\mathrm{mg}$ of $\mathrm{Co} / \mathrm{kg}$ of BW per day, administered in 3 equal doses at 8 -h intervals. Cobalt acetate had no influence on intake or milk fat and protein concentrations, whereas treatments Co6 and Co9 tended to lower milk yield. Results on rumen parameters showed no effects on rumen fermentation, FA composition, or bacterial community structure. Administration of Co acetate decreased milk concentrations of FA containing a cis-9 double bond and SCD product:substrate ratios, consistent with an inhibition of SCD activity in the ovine mammary gland. Temporal changes in milk fat composition indicated that the effects of treatments were evident within $3 \mathrm{~d}$ of dosing, with further changes being apparent after $6 \mathrm{~d}$ and reverting to pretreatment values by d 6 after administration. Effect on milk FA composition did not differ substantially in response to incremental doses of Co acetate. On average, Co decreased milk cis-9 10:1/10:0, cis-9 12:1/12:0, cis-9 14:1/14:0, cis-9 16:1/16:0, cis-9 17:1/17:0, cis-9 18:1/18:0, and cis-9,trans-11 18:2/trans-11 18:1 concentration ratios by $30,32,38,33,21,24$, and $25 \%$, respectively. Changes in milk fat cis-9 10:1, cis-9 12:1,
\end{abstract}

Received August 1, 2013.

Accepted October 10, 2013.

${ }^{1}$ Corresponding author: p.frutos@csic.es and cis-9 14:1 concentrations to Co treatment indicated that 51\% of cis-9 18:1 and cis-9,trans-11 18:2 secreted in milk originated from $\Delta^{9}$-desaturation. In conclusion, results demonstrated the potential of oral Co administration for the estimation of endogenous synthesis of FA containing a cis-9 double bond in the mammary gland of lactating ruminants. Indirect comparisons suggest that the effects of Co differ between sheep and cattle.

Key words: endogenous synthesis, $\Delta^{9}$-desaturase, mammary gland, sheep

\section{INTRODUCTION}

Based on the potential benefits to human health, there has been considerable interest in developing nutritional strategies for modulating the composition of ruminant milk fat, with increases in cis-9 18:1 and cis-9,trans-11 conjugated linoleic acid being considered desirable targets (Lock and Bauman, 2004).

Milk fat synthesis in ruminants involves a highly regulated and coordinated uptake of FA from peripheral circulation and de novo synthesis of FA, with a proportion of these being desaturated before esterification (Shingfield et al., 2010; Bernard et al., 2013). Stearoyl-CoA desaturase (SCD) plays a key role in mammary lipogenesis in ruminants (Palmquist et al., 2005; Bernard et al., 2013), being responsible for the majority of cis-9,trans-11 conjugated linoleic acid and a significant amount of cis-9 18:1 secreted in bovine (Griinari et al., 2000; Mosley et al., 2006), caprine (Bernard et al., 2010), and ovine (Bichi et al., 2012) milk. However, estimates of endogenous synthesis of these FA in lactating sheep are confined to 1 recent investigation (Bichi et al., 2012).

Earlier studies discovered rather serendipitously that administration of Co in the form of Co-EDTA (Shingfield et al., 2008) or Co acetate (Taugbøl et al., 2008; Karlengen et al., 2012) to lactating cows decreased milk fat concentrations of FA containing a cis-9 double bond. Intramuscular injections of Co acetate were also reported to induce similar changes in milk fat composi- 
tion in lactating sows (Karlengen et al., 2011). However, no reports exist on the effects of Co on milk fat composition in sheep. Preliminary assays indicated that administration of Co acetate in primiparous lactating ewes at a dose of ca. $3 \mathrm{mg}$ of $\mathrm{Co} / \mathrm{kg}$ of $\mathrm{BW}$ per day, equivalent to that used in cows (Shingfield et al., 2006, 2008), had discernible but rather small effects on milk FA composition, whereas a higher dose of $10 \mathrm{mg}$ of $\mathrm{Co} /$ $\mathrm{kg}$ of BW per day induced a severe depression in intake and milk yield (P. Frutos, G. Hervás, and P. G. Toral, unpublished data). These initial findings point toward species differences in mammary lipogenesis (Shingfield et al., 2010), and emphasize the importance of defining milk fat responses to a range of doses of Co in ovines.

Even though the mode of action is not known, administration of Co may represent a low-cost alternative to other compounds (e.g., sterculic acid or ${ }^{13} \mathrm{C}$-labeled FA) used to estimate the activity of the SCD enzymatic system. In lactating ruminants, the mammary gland is the major site of $\Delta^{9}$-desaturation and endogenous synthesis of cis-9 FA-containing FA (Kinsella, 1972; Mosley et al., 2006; Bernard et al., 2013). Although Co may influence the desaturation of FA in all tissues, the effects on milk FA composition could be expected to be the most pronounced during lactation.

The present investigation was, therefore, conducted to examine the effects of oral administration of 3 doses of Co acetate on intake, rumen function, and milk production and fat composition in lactating sheep. Particular emphasis was placed on measuring changes in the concentration of FA containing a cis-9 double bond, and on estimating endogenous synthesis of cis-9 18:1 and cis-9,trans-11 18:2 in the mammary gland.

\section{MATERIALS AND METHODS}

\section{Animals, Experimental Design, and Management}

All experimental procedures were approved and completed in accordance with the Spanish Royal Decree $53 / 2013$ for the protection of animals used for experimental purposes. Twenty lactating Assaf ewes (BW $=78.3 \pm 2.12 \mathrm{~kg} ; \mathrm{DIM}=81 \pm 1.5)$ were housed in individual tie-stalls and allocated to 1 of 4 groups ( $\mathrm{n}=$ 5), balanced according to milk production and composition, BW, DIM, and parity. All ewes were fed a TMR (50:50 forage:concentrate ratio, on a DM basis) based on alfalfa hay (particle size $>4 \mathrm{~cm}$ ) and concentrates (formulation and chemical composition shown in Table 1), offered to ensure ad libitum intakes, twice daily at 0900 and 1900 h. Ewes had continuous access to clean drinking water.

Each group of 5 ewes was randomly assigned to 1 of the following 4 experimental treatments: $0 \mathrm{mg}$ of $\mathrm{Co} /$ $\mathrm{kg}$ of BW per day (control), $3 \mathrm{mg}$ of $\mathrm{Co} / \mathrm{kg}$ of $\mathrm{BW}$ per day (Co3), $6 \mathrm{mg}$ of $\mathrm{Co} / \mathrm{kg}$ of $\mathrm{BW}$ per day (Co6), or $9 \mathrm{mg}$ of $\mathrm{Co} / \mathrm{kg}$ of BW per day (Co9). The experiment comprised a pretreatment adaptation ( $\mathrm{d}-15$ to 0 ), a treatment (d 1 to 6$)$, and a posttreatment (d +1 to +10 ) period. During the 6 -d treatment period, Co supplied in the form of cobalt(II) acetate tetrahydrate (403024; Sigma-Aldrich, Madrid, Spain) was dissolved in $450 \mathrm{~mL}$ of water and administered orally. Sheep were drenched with one-third of the daily dose at 8-h intervals, at 0800,1600 , and $2400 \mathrm{~h}$. Oral drenches of water were offered according to the same regimen to ewes assigned to the control group. All animals were milked at approximately 0830 and $1830 \mathrm{~h}$ in a dedicated $1 \times$ 10 stall milking parlor (DeLaval, Madrid, Spain).

\section{Measurements and Sampling Procedures}

Diets. Samples of the TMR offered and refusals were collected and weighed daily, stored at $-30^{\circ} \mathrm{C}$, and then freeze-dried before chemical analysis.

Milk. Daily milk yield was recorded on the last day of the pretreatment period $(\mathrm{d} 0)$, and during the treatment $(\mathrm{d} 3,5$, and 6$)$ and posttreatment $(\mathrm{d}+6$ and +10$)$ periods. At the same time, individual milk samples were collected and composited according to morning and evening milk yields. One aliquot of composite milk

Table 1. Formulation and chemical composition of the experimental diet

\begin{tabular}{|c|c|c|}
\hline Composition & $\mathrm{TMR}^{1}$ & SEM \\
\hline \multicolumn{3}{|l|}{ Ingredient, $\mathrm{g} / \mathrm{kg}$ of fresh matter } \\
\hline Dehydrated alfalfa hay & 500 & - \\
\hline Whole corn grain & 140 & - \\
\hline Whole wheat grain & 100 & - \\
\hline Soybean meal solvent $44 \% \mathrm{CP}$ & 150 & - \\
\hline Sugar beet pulp (pellets) & 50 & - \\
\hline Molasses (liquid) & 40 & - \\
\hline Mineral supplement ${ }^{2}$ & 18 & - \\
\hline Vitamin supplement $^{3}$ & 2 & - \\
\hline \multicolumn{3}{|l|}{ Chemical composition, $\mathrm{g} / \mathrm{kg}$ of DM } \\
\hline $\mathrm{OM}$ & 900 & 3.2 \\
\hline $\mathrm{CP}$ & 187 & 6.1 \\
\hline $\mathrm{NDF}$ & 311 & 24.3 \\
\hline Total FA & 17.7 & 1.34 \\
\hline \multicolumn{3}{|l|}{ FA composition, $\mathrm{g} / 100 \mathrm{~g}$ of total FA } \\
\hline $16: 0$ & 24.7 & 0.73 \\
\hline $18: 0$ & 5.3 & 0.19 \\
\hline cis-9 18:1 & 12.8 & 0.67 \\
\hline $18: 2 \mathrm{n}-6$ & 34.6 & 1.22 \\
\hline $18: 3 n-3$ & 13.4 & 1.31 \\
\hline \multicolumn{3}{|c|}{$\begin{array}{l}{ }^{1} \mathrm{n}=6 . \\
{ }^{2} \text { Contained }(\mathrm{g} / \mathrm{kg}) \mathrm{CaCO}_{3}(556), \mathrm{Ca}_{2} \mathrm{HPO}_{4}(222) \text {, and } \mathrm{NaCl}(222) . \\
{ }^{3} \mathrm{VITAFAC} \text { Ovino } 0.2 \% \mathrm{AC}(\mathrm{DSM} \text { Nutritional Products S.A., Madrid, } \\
\text { Spain). Declared as containing vitamin A }(4,000,000 \mathrm{IU} / \mathrm{kg}), \text { vitamin } \\
\mathrm{D}_{3}(1,000,000 \mathrm{IU} / \mathrm{kg}), \text { vitamin E }(5 \mathrm{~g} / \mathrm{kg}), \mathrm{Fe}(17.5 \mathrm{~g} / \mathrm{kg}), \mathrm{Mn}(20 \mathrm{~g} / \\
\mathrm{kg}), \mathrm{Co}(50 \mathrm{mg} / \mathrm{kg}), \mathrm{I}(250 \mathrm{mg} / \mathrm{kg}), \mathrm{Zn}(15 \mathrm{~g} / \mathrm{kg}), \mathrm{Se}(100 \mathrm{mg} / \mathrm{kg}) \text {, } \\
\text { sepiolite }(100 \mathrm{~g} / \mathrm{kg}), \mathrm{Ca}(26.2 \mathrm{~g} / \mathrm{kg}) \text {, and } \mathrm{Mg}(6.15 \mathrm{~g} / \mathrm{kg}) .\end{array}$} \\
\hline
\end{tabular}


was stored at $-30^{\circ} \mathrm{C}$ until analyzed for milk FA composition, whereas another was preserved with natamycin (Broad Spectrum Microtabs II; D \& F Control Systems Inc., Dublin, CA) and stored at $4^{\circ} \mathrm{C}$ until analyzed for fat, CP, lactose, and TS.

Rumen Fluid. Following an overnight fast, rumen fluid was obtained by stomach tube from each ewe after morning milking on $\mathrm{d}+1$ of the posttreatment period. Immediately after collection, the fluid was strained through 2 layers of muslin cloth, the $\mathrm{pH}$ (GLP22 $\mathrm{pH}$ meter; Crison Instruments SA, Barcelona, Spain) was measured, and a 4-mL subsample was acidified with 4 $\mathrm{mL}$ of $0.2 \mathrm{M} \mathrm{HCl}$ for ammonia determinations. Further 4- and $0.8-\mathrm{mL}$ aliquots of strained ruminal fluid were taken, respectively, for the analysis of lactic acid and VFA (deproteinized with $0.5 \mathrm{~mL}$ of $20 \mathrm{~g} / \mathrm{L}$ metaphosphoric and $4 \mathrm{~g} / \mathrm{L}$ crotonic acids in $0.5 \mathrm{M} \mathrm{HCl}$ ). All these samples were stored at $-30^{\circ} \mathrm{C}$ until analysis. Additional subsamples (ca. $50 \mathrm{~mL}$ ) of rumen fluid were also collected, immediately frozen at $-80^{\circ} \mathrm{C}$, freeze-dried, and stored at $-80^{\circ} \mathrm{C}$ until analyzed for FA composition and bacterial community structure.

\section{Chemical Analysis}

Diets. Samples were analyzed for DM (ISO 6496; ISO, 1999a), ash (ISO 5984; ISO, 2002), and CP (ISO 5983-2; ISO, 2009). Neutral detergent fiber content was determined according to Mertens (2002), using an Ankom $^{2000}$ fiber analyzer (Ankom Technology Corp., Macedon, NY). Analysis was made using sodium sulfite and $\alpha$-amylase, and expressed on a residual ash basis. Fatty acid methyl esters (FAME) of lipid in freeze-dried samples of TMR were prepared in a 1-step extractiontransesterification procedure using chloroform (Sukhija and Palmquist, 1988) and $2 \%$ (vol/vol) sulfuric acid in methanol (Shingfield et al., 2003), and cis-12 tridecenoate (Larodan Fine Chemicals AB, Malmö, Sweden) as an internal standard, because of a low abundance in analyzed samples and the elution of the cis-12 13:0 methyl ester in the absence of interference with other FAME during GC analysis.

Milk. Fat, CP, lactose, and TS concentrations were determined by infrared spectrophotometry (ISO 9622; ISO, 1999b) using a MilkoScan FT6000 analyzer (Foss Electric A/S, Hillerød, Denmark). Lipid in $1 \mathrm{~mL}$ of milk were extracted using diethyl ether and hexane (5:4, vol/vol) and transesterified to FAME using freshly prepared methanolic sodium methoxide as a catalyst (Shingfield et al., 2003). Methyl esters were separated and quantified using a gas chromatograph (Agilent 7890A GC System; Agilent Technologies Inc., Santa Clara, CA) equipped with a flame-ionization detector and a 100-m fused silica capillary column $(0.25-\mathrm{mm}$ i.d., 0.2- $\mu \mathrm{m}$ film thickness; CP-SIL 88, CP7489; Varian Ibérica S.A., Madrid, Spain) and hydrogen as the carrier gas $(207 \mathrm{kPa}, 2.1 \mathrm{~mL} / \mathrm{min})$. The total FAME profile in a $2-\mu \mathrm{L}$ sample volume at a split ratio of 1:50 was determined using a temperature gradient program (Shingfield et al., 2003). Isomers of 18:1 were further resolved in a separate analysis under isothermal conditions at $170^{\circ} \mathrm{C}$ (Shingfield et al., 2003). Peaks were identified based on retention time comparisons with commercially available authentic standards $(\mathrm{Nu}-\mathrm{Chek}$ Prep, Elysian, MN; Sigma-Aldrich; and Larodan Fine Chemicals AB), cross-referencing with chromatograms reported in the literature (Shingfield et al., 2003; Kramer et al., 2008; Halmemies-Beauchet-Filleau et al., 2011) and comparing with reference samples for which the FA composition was determined based on GC analysis of FAME and GC-MS analysis of corresponding 4,4-dimethyloxazoline derivates (Toral et al., 2010; Bichi et al., 2013).

Rumen Fluid. Ammonia and lactic acid concentrations were determined by colorimetric methods and VFA by GC, using crotonic acid as an internal standard (Toral et al., 2011). Lipid in $200 \mathrm{mg}$ of freeze-dried strained rumen fluid was extracted using a mixture of hexane and isopropanol $(3: 2, \mathrm{vol} / \mathrm{vol})$ and converted to FAME by sequential base-acid catalyzed transesterification (Toral et al., 2010). Total FAME profile was determined by GC using the same chromatograph and temperature gradient applied for the analysis of milk fat.

Freeze-dried samples of rumen fluid were thoroughly mixed before DNA extraction (Belenguer et al.., 2010) and terminal restriction fragment length polymorphism (T-RFLP) analysis of bacterial 16S rRNA genes. The DNA was extracted from duplicate samples, combined, and used as templates. Concentrations of DNA were determined by spectrophotometry (NanoDrop ND1000 Spectrophotometer; NanoDrop Technologies Inc., Wilmington, DE). The T-RFLP analysis was performed using a universal bacteria-specific primer pair set and 3 restriction enzymes (HhaI, MspI, and HaeIII; Belenguer et al., 2010). The lengths of the fluorescently labeled terminal restriction fragments were determined with the size standard ET-900-R (GE Healthcare Life Sciences, Buckinghamshire, UK) using the GeneMarker analysis software (SoftGenetics LLC, State College, PA).

\section{Calculations and Statistical Analysis}

Differences in the concentrations of cis-9 10:1, cis-9 12:1, and cis-9 14:1 measured on the last day of the pretreatment period (d 0 ) and the average over d 5 and 6 of Co administration were used as an indication of incomplete SCD inhibition, allowing endogenous 
synthesis of cis-9 18:1 and cis-9,trans-11 18:2 in the mammary glands to be estimated (Griinari et al., 2000; Kay et al., 2004; Bichi et al., 2012).

All statistical analyses were performed using the SAS software package (version 9.3; SAS Institute Inc., Cary, $\mathrm{NC}$ ). Intake and milk production and FA composition data were analyzed by a one-way analysis of covariance (ANCOVA) using PROC MIXED of SAS with a model that included the fixed effects of experimental treatment (mean values over d 5 and 6 of Co administration) and the initial measure at the start of the experiment (d 0) as a covariate. Orthogonal polynomial contrasts were used to evaluate linear and quadratic components of the response to incremental amounts of Co administration. Data recorded over the course of the experiment were subjected to ANOVA for repeated measures using PROC MIXED of SAS and assuming a covariance structure fitted on the basis of Schwarz's Bayesian information model fit criterion. The statistical model included the fixed effects of treatment, experimental day, and their interaction, and the initial record measured on d 0 as a covariate. Measurements of ruminal fermentation characteristics and FA composition were analyzed by one-way ANOVA to test the fixed effect of treatment, using PROC MIXED of SAS. For all statistical models, animal nested within treatment was designated as the random effect. Differences were declared significant at $P<0.05$ and a trend toward significance at $P>0.05$ to 0.10 . Covariate-adjusted least squares means are reported.

Data from T-RFLP (size, base pairs, and peak area for each terminal restriction fragment) were analyzed as outlined by Abdo et al. (2006). Hierarchical clustering with the Ward method based on Jaccard distances to construct a dendrogram and analysis of similarity based on the Bray-Curtis similarity matrix were performed using the $\mathrm{R}$ software (version 2.13.1; http:// www.r-project.org). The analysis of similarity produces a test statistic (R-value) that indicates the extent to which groups differ, with $\mathrm{R}>0.75$ being well separated, $0.75>\mathrm{R}>0.50$ overlapping but being clearly different, and $\mathrm{R}<0.25$ being barely separable (Frey et al., 2010).

\section{RESULTS}

\section{Intake, Milk Production, and Milk Composition}

Oral administration of Co had no influence on DMI, but decreased $(P<0.01)$ milk yield in ewes offered the Co6 and Co9 treatments (Table 2). As a consequence, Co9 decreased $(P<0.05)$ milk CP, lactose, and TS yields, and Co6 decreased lactose yield $(P<0.05)$ relative to the control. Administration of Co had no effect $(P>0.10)$ on milk fat, $\mathrm{CP}$, or TS concentrations, whereas lactose content was ca. $2 \%$ lower $(P=0.03)$ for Co9 compared with Co3.

\section{Milk FA Composition}

Administration of Co decreased $(P<0.01)$ the relative abundance of monoenoic $\mathrm{FA}$ containing a cis9 double bond (cis-9 10:1, cis-9 12:1, cis-9 14:1, cis9 16:1, cis-9 17:1, and cis-9 18:1; Table 3). However, changes in the relative concentration of cis-9-containing PUFA (cis-9,trans-11 18:2 and cis-9,trans-12 18:2) were less pronounced, and for certain isomers, including cis9,trans-13 18:2, did not differ $(P>0.05)$ compared with the control. Milk fat concentrations of substrates for SCD were not affected $(P>0.10)$ by Co administration, other than an increase in 14:0 at the highest dose (Co9).

Table 2. Effect of oral administration of Co acetate on intake and milk production and composition of lactating ewes

\begin{tabular}{|c|c|c|c|c|c|c|c|}
\hline \multirow[b]{2}{*}{ Item } & \multicolumn{4}{|c|}{ Treatment $^{1}$} & \multirow[b]{2}{*}{$\mathrm{SED}^{2}$} & \multirow[b]{2}{*}{$P$-value } & \multirow[b]{2}{*}{ Contrast } \\
\hline & Control & Co3 & Co6 & Co9 & & & \\
\hline \multicolumn{5}{|l|}{ Yield, g/d } & & & \\
\hline Fat & 124.7 & $\begin{array}{l}2,000 \\
113.8\end{array}$ & 110.3 & $\begin{array}{r}1,950 \\
\quad 108.1\end{array}$ & $\begin{array}{r}47.0 \\
7.40\end{array}$ & $\begin{array}{r}<0.01 \\
0.12\end{array}$ & Q \\
\hline $\mathrm{CP}$ & $109.3^{\mathrm{a}}$ & $106.9^{\mathrm{ab}}$ & $103.0^{\mathrm{ab}}$ & $101.8^{\mathrm{b}}$ & 2.35 & 0.02 & $\mathrm{Q}$ \\
\hline \multicolumn{8}{|c|}{ Composition, $\mathrm{g} / \mathrm{kg}$} \\
\hline Fat & 58.6 & 56.4 & 55.0 & 57.5 & 2.82 & 0.57 & \\
\hline $\mathrm{CP}$ & 51.5 & 52.6 & 51.9 & 53.3 & 0.78 & 0.13 & \\
\hline Lactose & $48.7^{\mathrm{ab}}$ & $48.9^{\mathrm{a}}$ & $48.4^{\mathrm{ab}}$ & $47.9^{\mathrm{b}}$ & 0.37 & 0.03 & $\mathrm{Q}$ \\
\hline TS & 167.7 & 165.6 & 163.9 & 166.2 & 3.04 & 0.63 & \\
\hline
\end{tabular}

\footnotetext{
${ }^{\mathrm{a}, \mathrm{b}}$ Within a row, means without a common superscript letter differ $(P<0.05)$.

${ }^{1}$ Supplying 0 (control), 3 (Co3), 6 (Co6), or 9 (Co9) mg of Co/kg of BW per day. Values represent the mean over d 5 and 6 of Co administration. ${ }^{2}$ Standard error of the difference.

${ }^{3}$ Indicates significant $(P<0.05)$ quadratic $(\mathrm{Q})$ components of the response to incremental Co administration.
} 
Table 3. Effect of oral administration of Co acetate on the composition of FA in milk of lactating ewes (treatment effects on additional FA in milk are reported in Supplemental Table S1, available at http://dx.doi.org/10.3168/jds.2013-7327)

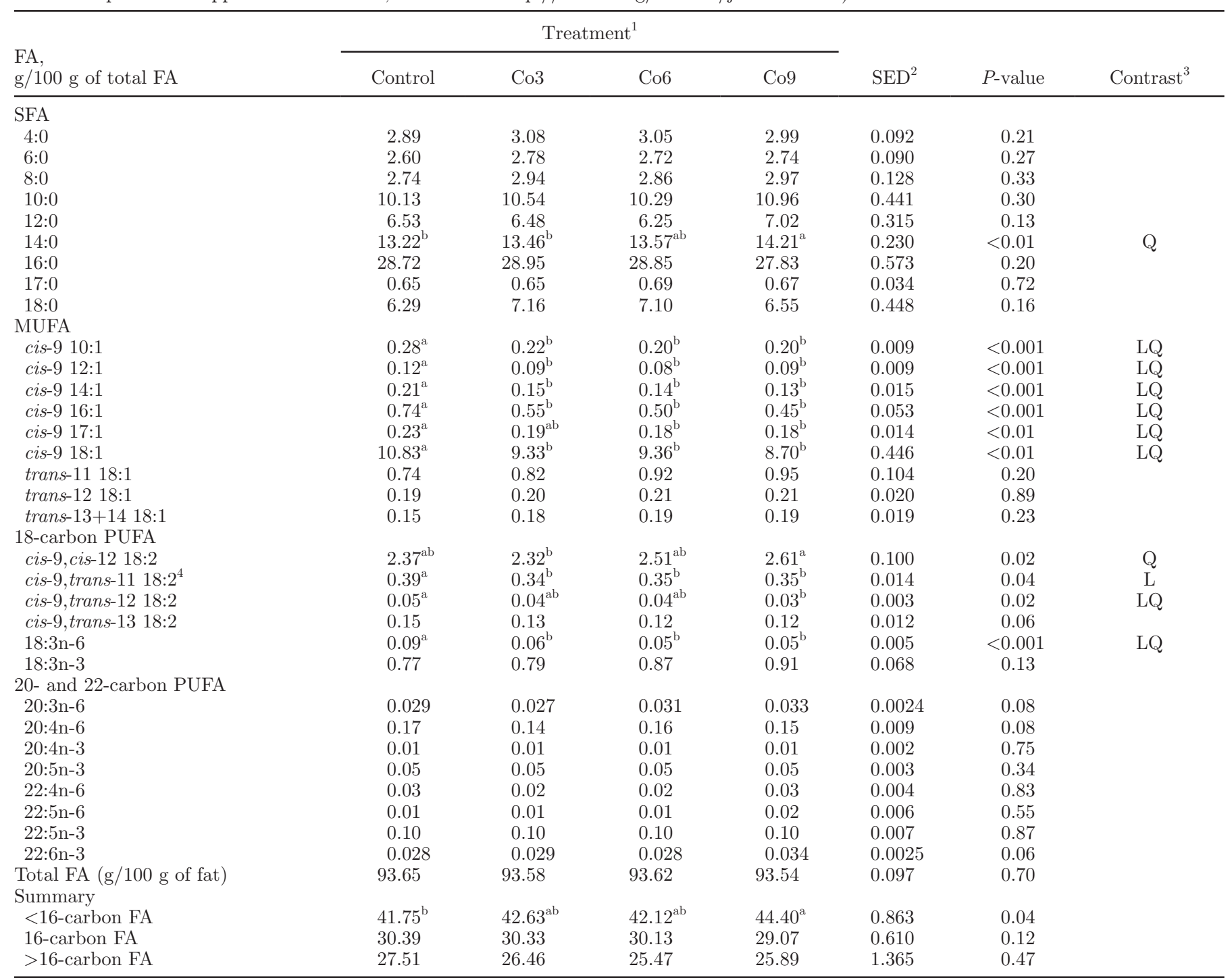

${ }^{\mathrm{a}, \mathrm{b}}$ Within a row, different superscript letters indicate significant differences $(P<0.05)$.

${ }^{1}$ Supplying 0 (control), 3 (Co3), 6 (Co6), or 9 (Co9) mg of Co/kg of BW per day. Values represent the mean over d 5 and 6 of Co administration. ${ }^{2}$ Standard error of the difference.

${ }^{3}$ Indicates significant $(P<0.05)$ linear $(\mathrm{L})$ or quadratic $(\mathrm{Q})$ components of the response to incremental Co administration.

${ }^{4}$ Contains trans-8,cis-10 18:2 and trans-7,cis-9 18:2 as minor components.

Concentrations of cis-9 10:1, cis-9 12:1, and cis-9 14:1 in milk fat were lowered, on average, by $30 \%$ (range of 22 to $38 \%$ ) during Co administration. Using this value to correct for decreases in $\Delta^{9}$-desaturation allowed us to estimate that more than half of cis-9 18:1 (range of 38 to $58 \%$ ) and cis-9,trans-11 18:2 (range of 43 to $66 \%$ ) secreted in milk was synthesized endogenously.

For all other FA in milk fat, administration of Co had relatively minor effects (see Table 3 and Supplemental Table S1, available at http://dx.doi.org/10.3168/ jds.2013-7327). Even though the Co9 treatment re- sulted in a marginal increase in the relative proportions of $<16$-carbon FA (i.e., those mainly synthesized in the mammary gland; $P<0.05$ ), those of 16 - and $>16$-carbon FA, as well as odd- and branched-chain FA, did not differ $(P>0.10$; Table 3$)$. Furthermore, Co had limited influence on n-6 PUFA concentrations, increasing ( $P$ $<0.05$ ) 18:2n-6, decreasing 18:3n-6, and with a trend $(P=0.08)$ toward higher $20: 3 \mathrm{n}-6$ and lower $20: 4 \mathrm{n}-6$ concentrations.

Overall, Co administration lowered $(P<0.05)$ in a quadratic manner milk fat concentration ratios of 
product:substrate for SCD, with the majority of the decrease being apparent in response to Co3 (Table 4). Differences in milk fat cis-9 10:1/10:0, cis-9 12:1/12:0, cis-9 14:1/14:0, cis-9 16:1/16:0, cis-9 17:1/17:0, cis-9 18:1/18:0, or cis-9,trans-11 18:2/trans-11 18:1 (mean response $-30,-32,-38,-33,-21,-24$, and $-25 \%$, respectively) were not proportional to the amount of administered Co. Relative to the control, only treatments Co6 and Co9 lowered the ratio for cis-9,trans-13 18:2/trans-13+14 18:1, whereas that of cis-9,trans-12 18:2/trans-12 18:1 was only decreased in response to Co9. Changes in milk fat SCD product:substrate concentration ratios (Figure 1) indicated that the effects of Co administration were evident within $3 \mathrm{~d}$ of dosing and generally recovered to pretreatment values by $\mathrm{d} 6$ after administration.

\section{Rumen Fermentation Characteristics, FA Composition, and Bacterial Community Structure}

Oral administration of Co had no effect $(P>0.10)$ on rumen $\mathrm{pH}$ (mean $\pm \mathrm{SEM} ; 7.05 \pm 0.115)$, ammonia $(279 \pm 30.4 \mathrm{mg} / \mathrm{L})$, lactate $(275 \pm 39.7 \mathrm{mg} / \mathrm{L})$, total VFA $(84.1 \pm 7.69 \mathrm{mmol} / \mathrm{L})$, or molar proportions of acetate, propionate, butyrate, and the sum of isobutyrate, isovalerate, valerate, and caproate $(65.5 \pm 0.74$, $15.6 \pm 1.03,13.1 \pm 0.83$, and $5.8 \pm 0.57 \mathrm{~mol} / 100 \mathrm{~mol}$, respectively). Consistent with the lack of changes in rumen fermentation characteristics, Co administration had no influence on the FA composition of strained rumen fluid, other than influencing $(P<0.05)$ trans9,trans-12 18:2 and cis-13 22:1 concentrations and a tendency $(P<0.10)$ to alter the relative abundance of 10-oxo-18:0, trans-16 18:1, and trans-11,trans-13 18:2 (Supplemental Table S2, available at http://dx.doi. org/10.3168/jds.2013-7327).
Hierarchical clustering analysis did not indicate a segregation of bacterial profiles based on Co treatments (Figure 2). For all samples, the analysis of similarity revealed low R-values $(<0.25 ; P>0.10)$, highlighting that Co had no discernible effects on the rumen bacterial community structure.

\section{DISCUSSION}

Administration of Co has been demonstrated to decrease milk concentration of FA containing a cis-9 double bond in lactating cows (Shingfield et al., 2008; Taugbøl et al., 2008; Karlengen et al., 2012) and sows (Karlengen et al., 2011) but no reports exist for sheep. Preliminary assays conducted by the current authors suggested that changes in ovine milk FA composition to Co were less pronounced than that reported in cattle. Most studies have examined the effects of Co administered as Co-EDTA or Co acetate, with both being equally efficacious, at least in the bovine (Taugbøl et al., 2008).

Cobalt has been used in the treatment of anemia, but in excessive amounts can lead to tissue and cellular toxicity (Simonsen et al., 2012). In the present study, no evidence existed to indicate that the amounts of $\mathrm{Co}$ administered over a 6-d interval induced clinical symptoms of toxicosis or had an adverse effect on animal performance, other than marginal decreases in milk yield that may be indicative of subclinical Co-induced toxicity in ewes offered the Co6 and Co9 treatments. Recent studies have also documented that ruminal infusions of Co acetate supplying up to $5.3 \mathrm{~g}$ of $\mathrm{Co} / \mathrm{d}$ lower DMI and milk yields in lactating cows (Karlengen et al., 2013).

Cobalt plays a critical role in the synthesis of vitamin $B_{12}$ by microorganisms in the rumen, but much

Table 4. Effect of oral administration of Co acetate on stearoyl-CoA desaturase product:substrate concentration ratios in milk of lactating ewes

\begin{tabular}{|c|c|c|c|c|c|c|c|}
\hline FA & \multicolumn{4}{|c|}{ Treatment $^{1}$} & $\mathrm{SED}^{2}$ & $P$-value & Contrast \\
\hline cis-9 10:1/10:0 & $0.028^{\mathrm{a}}$ & $0.021^{\mathrm{b}}$ & $0.020^{\mathrm{b}}$ & $0.018^{\mathrm{b}}$ & 0.0013 & $<0.001$ & LQ \\
\hline cis-9 14:1/14:0 & $0.016^{\mathrm{a}}$ & $0.011^{\mathrm{b}}$ & $0.010^{\mathrm{b}}$ & $0.009^{\mathrm{b}}$ & 0.0010 & $<0.001$ & LQ \\
\hline cis-9 16:1/16:0 & $0.026^{\mathrm{a}}$ & $0.019^{\mathrm{b}}$ & $0.017^{\mathrm{b}}$ & $0.016^{\mathrm{b}}$ & 0.0017 & $<0.001$ & LQ \\
\hline cis-9 17:1/17:0 & $0.346^{\mathrm{a}}$ & $0.299^{\mathrm{b}}$ & $0.264^{\mathrm{b}}$ & $0.254^{\mathrm{b}}$ & 0.0168 & $<0.001$ & LQ \\
\hline cis-9,trans-12 18:2/trans- 12 18:1 & $0.242^{\mathrm{a}}$ & $0.180^{\mathrm{ab}}$ & $0.187^{\mathrm{ab}}$ & $0.166^{\mathrm{b}}$ & 0.0231 & 0.02 & LQ \\
\hline cis-9,trans-13 18:2/trans- $13+14$ 18:1 & $0.958^{\mathrm{a}}$ & $0.705^{\mathrm{ab}}$ & $0.672^{\mathrm{b}}$ & $0.687^{\mathrm{b}}$ & 0.0862 & 0.01 & $\mathrm{LQ}$ \\
\hline
\end{tabular}

\footnotetext{
${ }_{\mathrm{a}, \mathrm{b}}$ Within a row, different superscript letters indicate significant differences $(P<0.05)$.

${ }^{1}$ Supplying 0 (control), 3 (Co3), 6 (Co6), or 9 (Co9) mg of Co/kg of BW per day. Values represent the mean over d 5 and 6 of Co administration. ${ }^{2}$ Standard error of the difference.

${ }^{3}$ Indicates significant $(P<0.05)$ linear $(\mathrm{L})$ or quadratic $(\mathrm{Q})$ components of the response to incremental Co administration.

${ }^{4}$ Contains trans-8,cis-10 18:2 and trans-7,cis-9 18:2 as minor components.
} 

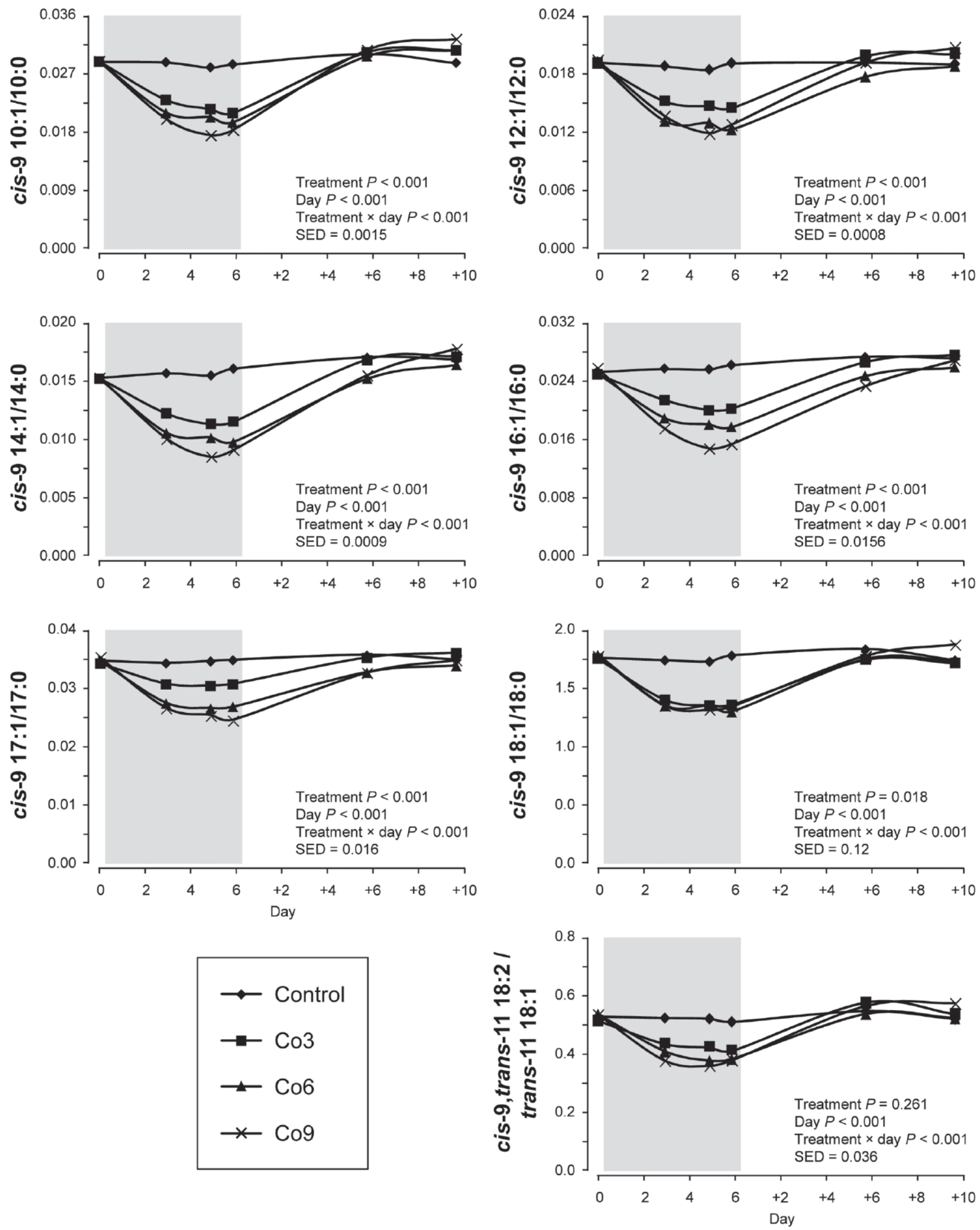

Figure 1. Temporal changes in the concentration ratio of product:substrate for stearoyl-CoA desaturase in milk from ewes before (d 0$)$, during $(\mathrm{d} 3,5$, and 6 ; gray shadow) and after $(\mathrm{d}+6$ and +10$)$ oral administration of Co acetate, supplying 0 (control), 3 (Co3), 6 (Co6), or 9 (Co9) $\mathrm{mg}$ of $\mathrm{Co} / \mathrm{kg}$ of BW per day. SED $=\mathrm{SE}$ of the difference. 
less is known about other possible influences on rumen function (Tiffany et al., 2003). In chelated form, Co has no effect on rumen fermentation (Udén et al., 1980) and, therefore, Co-EDTA has been used widely as a marker of liquid passage kinetics for estimating nutrient flow at the omasum or duodenum. More recent studies (Taugbøl et al., 2008) have also shown that oral administration of $\mathrm{Co}$ either in the form of Co acetate or Co-EDTA does not appear to influence rumen function in lactating cows. The present study provides further evidence that Co acetate does not alter rumen fermentation characteristics in lactating sheep. In addition, the lack of treatment effects on ruminal FA composition or bacterial community structure do not support Co causing substantial changes in ruminal lipid metabolism or microbial populations.

Oral administration of Co decreased milk concentrations of FA containing a cis-9 double bond, consistent with an inhibition of SCD activity in the ovine mammary gland. Temporal changes in cis-9-containing FA and SCD product:substrate ratios showed that the effects of Co were evident within $3 \mathrm{~d}$ of dosing, with further changes occurring until d 6. Studies in lactating cows also indicate that the effect of Co administration as Co-EDTA (Shingfield et al., 2006, 2008) or Co acetate (Taugbøl et al., 2008, 2010; Karlengen et al., 2012) on milk fat composition occurs within $72 \mathrm{~h}$, reaching a nadir between 6 and $9 \mathrm{~d}$.

Based on reports in cattle (Karlengen et al., 2013), it was expected that incremental oral administration of Co acetate would induce dose-dependent changes in milk fat composition in lactating sheep. In contrast, the magnitude of decreases in milk fat SCD product:substrate concentration ratios did not differ substantially in response to the amount of Co dosed, being much lower $(27.8 \pm 1.58 \%)$ than that reported in cattle (46.8 $\pm 1.70 \%$; Shingfield et al., 2006, 2008; Taugbøl et al., 2008, 2010; Karlengen et al., 2012) on the basis of the amount of Co administered per unit of BW. These findings were against expectations, given that infusions of sterculic acid or oil, which contain 2 known inhibitors of SCD (7-2-octyl-1-cyclopropenyl heptanoic acid and 8-2-octyl-1-cyclopropenyl octanoic acid), result in similar changes in milk fat composition in lactating ewes (Bichi et al., 2012) and cows (Griinari et al., 2000; Corl et al., 2001; Kay et al., 2004), even if the mechanisms and mode of action explaining the effects of Co and cyclopropene FA on milk fat may differ. Studies with the 3T3L1 cell line suggest that sterculic acid and malvalic acid inhibit SCD activity due to the formation of a non-dissociating enzyme-sterculoyl-CoA complex, preventing normal desaturation, a process that occurs in the absence of altered transcription or translation of the SCD1 gene (Gomez et al., 2003). It

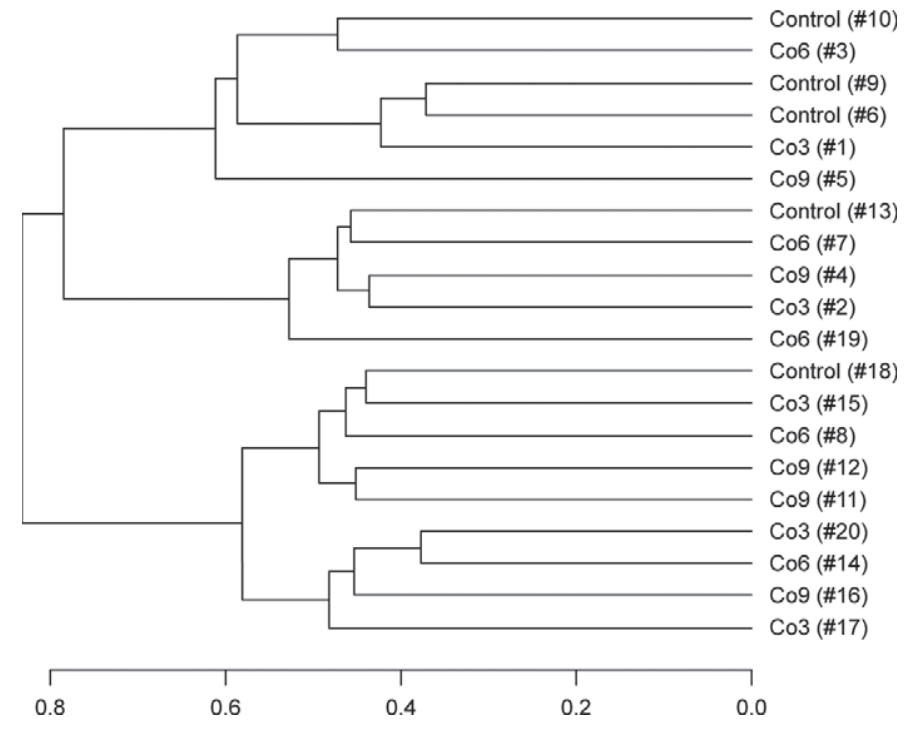

Figure 2. Dendrogram of terminal restriction fragment length polymorphism (T-RFLP) profiles of total bacteria in rumen fluid of lactating ewes receiving oral administration of Co acetate, supplying 0 (control), 3 (Co3), 6 (Co6), or 9 (Co9) $\mathrm{mg}$ of $\mathrm{Co} / \mathrm{kg}$ of $\mathrm{BW}$ per day. Cluster analysis was based on the Ward method and Jaccard distances. Values in parentheses refer to the number of each animal.

therefore follows that differences in the response to Co are probably more related to variations in the absorption and transport of this element into the mammary epithelial cell, rather than specific between-species differences in the effects of Co on SCD per se.

The SCD enzyme complex contains 3 components, NADH-cytochrome $b_{5}$ reductase, cytochrome $b_{5}$, and the terminal desaturase. During desaturation, electron transfer is facilitated by a catalytic di-iron protein complex of the terminal desaturase (Nakamura and Nara, 2004). Even though the mode of action of Co is not known, it has been suggested that $\mathrm{Co}^{2+}$ may displace $\mathrm{Fe}^{2+}$, resulting in an iron-depleted SCD species, causing an overall decrease in the desaturation of acyl-CoA substrates, with the effects being most pronounced in the mammary gland during lactation (Shingfield et al., 2008; Taugb $\varnothing l$ et al., 2010). An alternative hypothesis has proposed that $\mathrm{Co}^{2+}$ has an indirect effect favoring the degradation of the heme group, thereby causing the release of $\mathrm{Fe}$ from cytochrome $b_{5}$ (Karlengen et al., 2012 , 2013). Both putative mechanisms would account for Co administration increasing milk Fe concentration (Karlengen et al., 2013), with changes in milk FA composition being independent of alterations in mammary $S C D 1$ gene expression, as appears to be the case in cattle (Karlengen et al., 2012; Vilkki et al., 2012).

Some changes in minor PUFA concentrations, in particular a trend for decreases in the concentration of $\Delta^{6}$ - and $\Delta^{5}$-desaturase products (18:3n-6 and 20:4n-6, respectively) and increases in the corresponding sub- 
strates (18:2n-6 and 20:3n-6, respectively) could be considered as evidence that Co may lower the activity of both desaturases, as indicated in previous studies with lactating cows (Taugb $\varnothing l$ et al., 2010; Karlengen et al., 2012). However, even though the 3 membranebound desaturases have a di-iron catalytic site, depend on cytochrome $b_{5}$ as an electron donor, and have an absolute requirement for oxygen (Nakamura and Nara, 2004), changes in plasma FA composition in cows (Karlengen et al., 2013) suggest that Co acts via a common mechanism to inhibit the activity of $\Delta^{9}$ - and $\Delta^{6}$-desaturases, but not of $\Delta^{5}$-desaturase.

Incorporation of 10:0, 12:0, and 14:0 FA in milk fat triacylglycerols is almost exclusively derived from de novo synthesis in the mammary gland, these FA serving as substrates for SCD, yielding cis-9 10:1, cis-9 12:1, and cis-9 14:1 products, respectively (Bauman and Davis, 1974). Decreases in milk fat SCD ratios for these FA provide strong evidence that milk fat composition responses to Co are mediated via effects on tissues rather than via changes in ruminal lipid metabolism and supply of FA available for incorporation into milk fat. These findings are supported by the lack of differences in ruminal VFA and FA profiles, particularly trans FA isomers that originate from biohydrogenation of dietary unsaturated FA by rumen microbial populations, during Co administration. Changes in milk fat composition to Co were also independent of substantial alterations in the proportion of FA derived from de novo synthesis or the peripheral circulation, suggesting that the mammary glands can accommodate alterations in the abundance of SCD products for milk fat triacylglycerol synthesis in the absence of substantial changes in de novo synthesis or uptake of FA.

Data on SCD product:substrate concentration ratios also provided some indications of inherent differences in SCD activity or substrate specificity between cows and sheep. Milk fat concentration ratios for cis-9 14:1/14:0 averaged 0.016 in the control, a value that is within the normal range for this species (approximately 0.0140.021; e.g., Nudda et al., 2005; Toral et al., 2011; Bichi et al., 2012), but much lower than reported for lactating cows (approximately 0.08-0.11; e.g., Kay et al., 2004; Mosley et al., 2006; Shingfield et al., 2008). This finding is of particular importance, given that variations in the ratio of cis-9 14:1 to 14:0 have often been used as a proxy for SCD activity (Griinari et al., 2000; Corl et al., 2001; Bichi et al., 2012). In goats, this ratio has been shown to provide more reliable estimates of mammary SCD activity compared with that for $\geq 16$-carbon FA (Bernard et al., 2013) but few data are available for shorter-chain FA. Furthermore, the higher ratio of cis-9 10:1/10:0 observed in the milk of ewes could be interpreted as a higher affinity of SCD for 10:0 than
14:0 in the ovine. In contrast, no major difference exists between cis-9 10:1/10:0 and cis-9 14:1/14:0 concentration ratios in bovine milk, with both being consistently higher compared with those reported in sheep (Kay et al., 2004; Shingfield et al., 2008; Taugbøl et al., 2008), irrespective of diet composition. Even though measurements of milk cis-9 10:1 and cis-9 12:1 concentrations may be useful in understanding between-species differences in mammary lipogenesis, they are seldom reported. Inferences in between-species differences in the functioning of the desaturase system made on the basis of SCD product:substrate concentrate ratios in milk would need to be confirmed based on measurements of mammary SCD mRNA, protein abundance, and activity.

In the present experiment, the decreases during Co administration in milk cis-9 10:1, cis-9 12:1, and cis-9 14:1, FA almost exclusively synthesized de novo, were used to provide correction factors to estimate endogenous synthesis of cis-9 18:1 and cis-9,trans-11 18:2 in the mammary glands. Estimates varied, depending on the SCD product:substrate concentration ratio used to correct for partial inhibition of SCD activity, from 38 to $58 \%$ for cis-9 $18: 1$, and from 43 to $66 \%$ for cis-9,trans-11 18:2, averaging $51 \%$ in both cases. An earlier study involving intravenous infusion of sterculic acid reported that 63 and $74 \%$ of cis-9 $18: 1$ and cis9,trans-11 18:2 secretion in ovine milk originates from endogenous desaturation of 18:0 and trans-11 18:1, respectively, in grazing sheep (Bichi et al., 2012). These values are higher than those observed in the present experiment, which may be related to differences in diet composition, and as a consequence, on the availability of specific 18-carbon biohydrogenation intermediates and 18:0 at the mammary gland. In cattle, endogenous synthesis of cis-9 18:1 and cis-9,trans-11 18:2 has been demonstrated to be higher in grazing cows (Kay et al., 2004) compared with cows offered diets based on conserved forages (e.g., Corl et al., 2001; Shingfield et al., 2008; Taugbøl et al., 2010), irrespective of the compound used to inhibit SCD. Additionally, lower estimates of endogenous cis-9,trans-11 18:2 synthesis in sheep than in cattle is consistent with a higher abundance of cis-9,trans-11 18:2 in ruminal digesta of ewes (approximately 0.2 to $0.35 \%$ of total FA; Toral et al., 2010, 2012) compared with lactating cows $(\leq 0.1 \%$; AbuGhazaleh et al., 2002; Boeckaert et al., 2008), supporting the hypothesis that a higher proportion of cis9,trans-11 18:2 secreted in ovine milk originates from the accumulation of cis-9,trans-11 18:2 in the rumen (Bichi et al., 2012). In the present study, the relative abundance of cis-9,trans-11 18:2 (0.34\% total FA) in ruminal fluid was typical for dairy sheep fed diets based on conserved forages (Toral et al., 2010, 2012). Overall, 
our data provide further evidence that administration of Co could be used as a low-cost alternative to other more expensive and involved methods for the estimation of SCD activity and desaturation of FA in the mammary gland of lactating ruminants.

\section{CONCLUSIONS}

Oral administration of Co acetate to lactating ewes decreased milk concentrations of FA containing a cis9 double bond, consistent with an inhibition of SCD activity. Changes in FA composition were largely independent of dose and of lower magnitude compared with responses in cows when comparisons are made on the amount of Co administered per unit of BW. The absence of effects on rumen fluid FA composition and bacterial community structure provided further evidence that Co influences lipid metabolism in ruminant tissues. Variations in milk fat composition in response to Co estimated that $51 \%$ of cis-9 $18: 1$ and cis-9,trans-11 18:2 secreted in milk originated from desaturation in the ovine mammary gland. Further studies involving labeled FA are required to validate these estimates and confirm the use of Co as a low-cost method for the estimation of endogenous synthesis of FA in lactating ruminants.

\section{ACKNOWLEDGMENTS}

This work was supported by the Spanish Ministry of Economy and Competitiveness (MINECO, Madrid, Spain; AGL2011-23700). The authors thank the research farm staff from the Instituto de Ganadería de Montaña (León, Spain) for their help in the fieldwork, and L. Barrios [Biostatistics Department, Consejo Superior de Investigaciones Cientificas (CSIC), Madrid, Spain] for helpful assistance with statistical analysis.

\section{REFERENCES}

Abdo, Z., U. M. E. Schüette, S. J. Bent, C. J. Williams, L. I. Forney, and P. Joyce. 2006. Statistical methods for characterizing diversity of microbial communities by analysis of terminal restriction fragment length polymorphisms of $16 \mathrm{~S}$ rRNA genes. Environ. Microbiol. 8:929-938.

AbuGhazaleh, A. A., D. J. Schingoethe, A. R. Hippen, K. F. Kalscheur, and L. A. Whitlock. 2002. Fatty acid profiles of milk and rumen digesta from cows fed fish oil, extruded soybeans or their blend. J. Dairy Sci. 85:2266-2276.

Bauman, D. E., and C. L. Davis. 1974. Biosynthesis of milk fat. Pages 31-75 in Lactation: A Comprehensive Treatise. Biosynthesis and Secretion of Milk: Diseases, Vol. 2. B. L. Larson and V. R. Smith, ed. Academic Press, London, UK.

Belenguer, A., P. G. Toral, P. Frutos, and G. Hervás. 2010. Changes in the rumen bacterial community in response to sunflower oil and fish oil supplements in the diet of dairy sheep. J. Dairy Sci. 93:3275-3286.
Bernard, L., C. Leroux, and Y. Chilliard. 2013. Expression and nutritional regulation of stearoyl-CoA desaturase genes in the ruminant mammary gland: Relationship with milk fatty acid composition. Pages 161-193 in Stearoyl-CoA Desaturase Genes in Lipid Metabolism. J. M. Ntambi, ed. Springer Science+Business Media, New York, NY.

Bernard, L., J. Mouriot, J. Rouel, F. Glasser, P. Capitan, E. PujosGuillot, J.-M. Chardigny, and Y. Chilliard. 2010. Effects of fish oil and starch added to a diet containing sunflower-seed oil on dairy goat performance, milk fatty acid composition and in vivo $\Delta$ 9-desaturation of $\left.{ }^{13} \mathrm{C}\right]$ vaccenic acid. Br. J. Nutr. 104:346-354.

Bichi, E., G. Hervás, P. G. Toral, J. J. Loor, and P. Frutos. 2013. Milk fat depression induced by dietary marine algae in dairy ewes: Persistency of milk fatty acid composition and animal performance responses. J. Dairy Sci. 96:524-532.

Bichi, E., P. G. Toral, G. Hervás, P. Frutos, P. Gómez-Cortés, M. Juárez, and M. A. de la Fuente. 2012. Inhibition of $\Delta^{9}$-desaturase activity with sterculic acid: Effect on the endogenous synthesis of cis-9 18:1 and cis-9, trans-11 18:2 in dairy sheep. J. Dairy Sci. 95:5242-5252.

Boeckaert, C., B. Vlaeminck, V. Fievez, L. Maignien, J. Dijkstra, and N. Boon. 2008. Accumulation of trans C18:1 fatty acids in the rumen after dietary algal supplementation is associated with changes in the Butyrivibrio community. Appl. Environ. Microbiol. 74:6923-6930.

Corl, B. A., L. H. Baumgard, D. A. Dwyer, J. M. Griinari, B. S. Phillips, and D. E. Bauman. 2001. The role of $\Delta^{9}$-desaturase in the production of cis-9, trans-11 CLA. J. Nutr. Biochem. 12:622-630.

Frey, J. C., A. N. Pell, R. Berthiaume, H. Lapierre, S. Lee, J. K. Ha, J. E. Mendell, and E. R. Angert. 2010. Comparative studies of microbial populations in the rumen, duodenum, ileum and faeces of lactating dairy cows. J. Appl. Microbiol. 108:1982-1993.

Gomez, F. E., D. E. Bauman, J. M. Ntambi, and B. G. Fox. 2003. Effects of sterculic acid on stearoyl-CoA desaturase in differentiating 3T3-L1 adipocytes. Biochem. Biophys. Res. Commun. 300:316-326.

Griinari, J. M., B. A. Corl, S. H. Lacy, P. Y. Chouinard, K. V. V. Nurmela, and D. E. Bauman. 2000. Conjugated linoleic acid is synthesized endogenously in lactating dairy cows by $\Delta^{9}$-desaturase. J. Nutr. 130:2285-2291.

Halmemies-Beauchet-Filleau, A., T. Kokkonen, A. M. Lampi, V. Toivonen, K. J. Shingfield, and A. Vanhatalo. 2011. Effect of plant oils and camelina expeller on milk fatty acid composition in lactating cows fed diets based on red clover silage. J. Dairy Sci. 94:4413-4430.

ISO (International Organization for Standardization). 1999a. Animal feeding stuffs - Determination of moisture and other volatile matter content. ISO 6496:1999. ISO, Geneva, Switzerland.

ISO (International Organization for Standardization). 1999b. Whole milk-Determination of milkfat, protein and lactose contentGuidance on the operation of mid-infrared instruments. ISO 9622:1999. ISO, Geneva, Switzerland.

ISO (International Organization for Standardization). 2002. Animal feeding stuffs - Determination of crude ash. ISO 5984:2002. ISO, Geneva, Switzerland.

ISO (International Organization for Standardization). 2009. Animal feeding stuffs - Determination of nitrogen content and calculation of crude protein content-Part 2: Block digestion and steam distillation method. ISO 5983-2:2009. ISO, Geneva, Switzerland.

Karlengen, I. J., O. M. Harstad, N. P. Kjos, B. Salbu, A. H. Aastveit, and O. Taugbøl. 2011. Cobalt reduces the $\Delta^{9}$-desaturase index of sow milk. J. Anim. Physiol. Anim. Nutr. (Berl.) 95:676-684.

Karlengen, I. J., O. M. Harstad, O. Taugbøl, I. Berget, A. H. Aastveit, and D. I. Våge. 2012. The effect of excess cobalt on milk fatty acid profiles and transcriptional regulation of $S C D, F A S N, D G A T 1$ and $D G A T 2$ in the mammary gland of lactating dairy cows. J. Anim. Physiol. Anim. Nutr. (Berl.) 96:1065-1073.

Karlengen, I. J., O. Taugbøl, B. Salbu, A. H. Aastveit, and O. M. Harstad. 2013. Effect of different levels of supplied cobalt on the fatty acid composition of bovine milk. Br. J. Nutr. 109:834-843. 
Kay, J. K., T. R. Mackle, M. J. Auldist, N. A. Thomson, and D. E. Bauman. 2004. Endogenous synthesis of cis-9, trans-11 conjugated linoleic acid in dairy cows fed fresh pasture. J. Dairy Sci. $87: 369-378$.

Kinsella, J. E. 1972. Stearoyl CoA as a precursor of oleic acid and glycolipids in mammary microsomes from lactating bovine: Possible regulatory step in milk triglyceride synthesis. Lipids 7:349-355.

Kramer, J. K. G., M. Hernandez, C. Cruz-Hernandez, J. Kraft, and M. E. R. Dugan. 2008. Combining results of two GC separations partly achieves determination of all cis and trans 16:1, 18:1, 18:2 and 18:3 except CLA isomers of milk fat as demonstrated using Ag-ion SPE fractionation. Lipids 43:259-273.

Lock, A. L., and D. E. Bauman. 2004. Modifying milk fat composition of dairy cows to enhance fatty acids beneficial to human health. Lipids 39:1197-1206.

Mertens, D. R. 2002. Gravimetric determination of amylase-treated neutral detergent fiber in feeds with refluxing in beakers or crucibles: Collaborative study. J. AOAC Int. 85:1217-1240.

Mosley, E. E., B. Shafii Dagger, P. J. Moate, and M. A. McGuire. 2006. Cis-9, trans-11 conjugated linoleic acid is synthesized directly from vaccenic acid in lactating dairy cattle. J. Nutr. 136:570-575.

Nakamura, M. T., and T. Y. Nara. 2004. Structure, function, and dietary regulation of $\Delta 6, \Delta 5$, and $\Delta 9$ desaturases. Annu. Rev. Nutr. 24:345-376.

Nudda, A., M. A. McGuire, G. Battacone, and G. Pulina. 2005. Seasonal variation in conjugated linoleic acid and vaccenic acid in milk fat of sheep and its transfer to cheese and ricotta. J. Dairy Sci. 88:1311-1319.

Palmquist, D. L., A. L. Lock, K. J. Shingfield, and D. E. Bauman. 2005. Biosynthesis of conjugated linoleic acid in ruminants and humans. Adv. Food Nutr. Res. 50:179-217.

Shingfield, K. J., S. Ahvenjärvi, V. Toivonen, A. Ärölä, K. V. V. Nurmela, P. Huhtanen, and J. M. Griinari. 2003. Effect of dietary fish oil on biohydrogenation of fatty acids and milk fatty acid content in cows. Anim. Sci. 77:165-179.

Shingfield, K. J., A. Ärölä, S. Ahvenjärvi, A. Vanhatalo, V. Toivonen, J. M. Griinari, and P. Huhtanen. 2008. Ruminal infusions of cobalt-EDTA reduce mammary $\Delta 9$-desaturase index and alter milk fatty acid composition in lactating cows. J. Nutr. 138:710-717.

Shingfield, K. J., L. Bernard, C. Leroux, and Y. Chilliard. 2010. Role of trans fatty acids in the nutritional regulation of mammary lipogenesis in ruminants. Animal 4:1140-1166.

Shingfield, K. J., V. Toivonen, A. Vanhatalo, P. Huhtanen, and J. M. Griinari. 2006. Indigestible markers reduce the mammary $\Delta^{9}$ - desaturase activity index and alter the milk fatty acid composition in cows. J. Dairy Sci. 89:3006-3010.

Simonsen, L. O., H. Harbak, and P. Bennekou. 2012. Cobalt metabolism and toxicology - A brief update. Sci. Total Environ. 432:210-215.

Sukhija, P. S., and D. L. Palmquist. 1988. Rapid method for determination of total fatty acid content and composition of feedstuffs and feces. J. Agric. Food Chem. 36:1202-1206.

Taugbøl, O., I. J. Karlengen. T. Bolstad, A. H. Aastveit, and O. M. Harstad. 2008. Cobalt supplied per os reduces the mammary $\Delta^{9}$-desaturase index of bovine milk. J. Anim. Sci. 86:3062-3068.

Taugbøl, O., I. J. Karlengen, B. Salbu, A. H. Aastveit, and O. M. Harstad. 2010. Intravenous injections of cobalt reduce fatty acid desaturation products in milk and blood of lactating cows. J. Anim. Physiol. Anim. Nutr. (Berl.) 94:635-640.

Tiffany, M. E., J. W. Spears, L. Xi, and J. Horton. 2003. Influence of dietary cobalt source and concentration on performance, vitamin $\mathrm{B}_{12}$ status, and ruminal and plasma metabolites in growing and finishing steers. J. Anim. Sci. 81:3151-3159.

Toral, P. G., A. Belenguer, K. J. Shingfield, G. Hervás, V. Toivonen, and P. Frutos. 2012. Fatty acid composition and bacterial community changes in the rumen fluid of lactating sheep fed sunflower oil plus incremental levels of marine algae. J. Dairy Sci. 95:794-806.

Toral, P. G., G. Hervás, E. Bichi, A. Belenguer, and P. Frutos. 2011 Tannins as feed additives to modulate ruminal biohydrogenation: Effects on animal performance, milk fatty acid composition and ruminal fermentation in dairy ewes fed a diet containing sunflower oil. Anim. Feed Sci. Technol. 164:199-206.

Toral, P. G., K. J. Shingfield, G. Hervás, V. Toivonen, and P. Frutos 2010. Effect of fish oil and sunflower oil on rumen fermentation characteristics and fatty acid composition of digesta in ewes fed a high concentrate diet. J. Dairy Sci. 93:4804-4817.

Udén, P., P. E. Colucci, and P. J. Van Soest. 1980. Investigation of chromium, cerium and cobalt as markers in digesta. Rate of passage studies. J. Sci. Food Agric. 31:625-632.

Vilkki, J., S. Viitala, H. Leskinen, J. Taponen, L. Bernard, and K. J. Shingfield. 2012. Effect of ruminal cobalt-EDTA infusion on milk fat composition and mammary lipogenic gene expression. Page 283 in Book of Abstracts of the 63rd Annual Meeting of the European Federation of Animal Science, Bratislava, Slovakia. Wageningen Academic Publishers, Wageningen, the Netherlands. 